\title{
Controls of seed quantity and quality on seedling recruitment of smith fir along altitudinal gradient in southeastern Tibetan Plateau
}

\author{
WANG Jing-sheng1,2 (iD http://orcid.org/oooo-0oo1-9363-5731; e-mail: wangjsh@igsnrr.ac.cn \\ FENG Ji-guang² (D http://orcid.org/oooo-0oo2-7342-9313; e-mail: fjg@ruc.edu.cn \\ CHEN Bao-xiong3 iD http://orcid.org/oooo-0oo1-7389-0858; e-mail: cbxiong@126.com

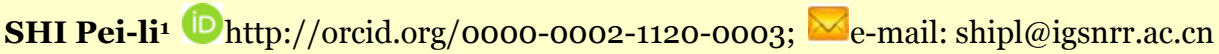 \\ ZHANG Jun-long4 iD http://orcid.org/oooo-0oo3-1259-9367; e-mail: zhangjl@ncsc.org.cn \\ FANG Jiang-ping5 (iD http://orcid.org/oooo-00o3-2559-0329; e-mail: xzfjp@sina.com \\ WANG Zhi-kai',2 i http://orcid.org/oooo-ooo3-1383-8673; e-mail: michealwzk@163.com \\ YAO Shuai-chen² iD http://orcid.org/oooo-0oo1-9614-9608; e-mail: yaoshuaichen@yeah.net \\ DING Lu-bin² iD http://orcid.org/oooo-0oo3-4377-1641; e-mail: 813665458@qq.com

\begin{abstract}
1 Lhasa Plateau Ecosystem Research Station, Key Laboratory of Ecosystem Network Observation and Modeling, Institute of Geographic Sciences and Natural Resources Research, Chinese Academy of Sciences, Beijing 100101, China

2 School of Environment and Natural Resources, Renmin University of China, Beijing 10o872, China

3 Rural Energy \& Environment Agency, Ministry of Agriculture of the Peoples Republic of China, Beijing 10o125, China

5 Tibet Agricultural and Animal Husbandry College, Tibet Linzhi 86oooo, China
\end{abstract} \\ 4 National Center for Climate Change Strategy and International Cooperation, Beijing 10oo38, China
}

Citation: Wang JS, Feng JG, Chen BX, et al. (2016) Controls of seed quantity and quality on seedling recruitment of smith fir along altitudinal gradient in southeastern Tibetan Plateau. Journal of Mountain Science 13(5). DOI: 10.1007/s11629-015-3761-x

(C) Science Press and Institute of Mountain Hazards and Environment, CAS and Springer-Verlag Berlin Heidelberg 2016

\begin{abstract}
Alpine treeline ecotones are harsh environment for tree establishment due to low temperature. Tree establishment at treelines requires favorable climate, suitable microsites, and viable seeds. But most researches have been addressed treeline microclimate and its effects on tree regeneration, the knowledge of seed quantity and quality and its controls on seedling recruitment were limited. We measured seed rain, soil seed bank, seed germination rate and seedling recruitment in natural forests in combination with seed transplanting manipulation to evaluate the controls of seed quantity and quality on seedling recruitment of Abies georgei var. smithii (smith fir) along altitudinal gradient, with
\end{abstract}

Received: 23 Novmeber 2015

Accepted: 29 January 2016 focus on treeline ecotone in the Sygera Mountains, southeastern Tibetan Plateau. Both seed quantity and seed quality of smith fir decreased with increasing altitude and was thereby associated with decline in seed germination rate. Seed quantity and seedling recruitment were better in north-facing slope than in south slope. The treeline ecotone above $4200 \mathrm{~m}$ appeared as the threshold altitude to sharply decrease seed quality and seedling recruitment. The emergence and overwintering rates of transplanting seeds from 3600-3800 $\mathrm{m}$ also went down remarkably above $4200 \mathrm{~m}$ at north-facing slope. It also underpins the fact that treeline ecotone is the bottleneck of seedling recruitment. Our results suggest that seed quantity and quality are the principal limitation of treeline upward advance. This study also provides evidence to 
support stable treeline position in southeastern Tibetan Plateau.

Keywords: Abies georgei var. smithii; Treeline; Seed rain; Soil seed bank; Seed quality; Seedling recruitment

\section{Introduction}

Alpine treeline refers to the ecological transition between mountain forest and alpine shrub or meadow (Peters 2002). It presents a unique alternate region in the habitat between the upper limit of the closed forest and sparse upright trees (Malanson 2001). Körner and Paulsen (2004) defined treeline as the altitude which group trees higher than three meters are capable of growing. Above treeline trees are often sparse and stunted because of harsh environment especially with low temperature. Treeline is sensitive to temperature variation and thus used as proxy and indicator of climate change (Körner 1998; MacDonald et al. 1998; Lloyd and Fastie 2002; Smith et al. 2003; Theurillat and Guisan 2001). Despite its importance, there exist debates on mechanism explanations of treeline formation and its dynamics. In global perspective, treeline positions are after all controlled by low temperature (Körner 1998; Holtmeier et al. 2003; Körner and Paulsen 2004) in terms of growth (carbon sink) limitation (Hoch and Körner2003; Shi et al. 2008). In local scale, treelines are subject to limitation associated with temperature and heat constraints (Holtmeier et al. 2003), disturbance (Holtmeier 2005), reproductive regeneration obstacle (Smith et al. 2003), and growth constraints (Press et al. 1998; Li et al. 2008). In any case, seedling recruitment and tree establishment are intimately associated with treeline dynamics. Tree establishment at treelines requires favorable climate, suitable microsites, and viable seeds (Wilmkinget al. 2012). In the past decades, most researches have been addressed treeline microclimate and its effects on tree regeneration (Maher and Germino 2006; Maher et al. 2005; Zhang et al. 2010; Liang et al. 2011; Liu and Luo 2011; Liu et al. 2011), however little is known about seed quantity and quality and its controls on seedling recruitment. Such knowledge is important to better understand to which extent the early part life stage is constrained in life form transition at treeline (Körner 2012). It will enhance the understanding of reproductive process and vegetation dynamics (Hofgaard 1993).

Seed quantity and quality, seedling recruitment and survival play important role in the stability and succession of tree population (Szwagrzyk et al. 2001). The successful tree establishment decides the future dynamics of the treeline. Generally, tree establishment depends on quality and quantity of seeds, germination conditions of seeds, and overwintering of seedlings and growth conditions of the sapling (Clark 1998; Silva and Tabarelli 2001). Therefore, understanding the information of seed quantity, quality dynamics, and recruitment has an important reference value in explaining the population dynamics and formation mechanism of treeline.

Tibetan Plateau has plenty of treeline species and diverse treelines. In southeastern Tibet Juniperus climbs up the high altitudes, and thereby forms one of the highest treelines (Wang et al. 2004; Miehe et al. 2007) over the world except Polylepis treeline in South American Andes (Hoch and Korner 2005). Liang et al. (2011) reported the highest and stable smith fir treeline of Abiesgeorgei var. smithii at 4360 in north-facing slope in the Sygera Mountains, southeastern Tibet. They attributed little change of treeline position over the past 200 years to no tree establishment above treeline despite abundant seedling recruitment in response to climate warming in the past decades. Shen et al. (2014) proposed that extreme low temperature caused freezing events were the exact cause of unchanged treeline position. Both studies explained dynamics in terms of seedling recruitment in response to microclimate. However, little is known about the seed amount, quality and its effects on seedling recruitment. Without such information, the reproduction and early life stage of tree establishment is not clear (Körner 2012). The related work is underrepresented due to tedious and time-consuming exploration (Smithet al. 2009). The seed and reproduction ecology will undoubtedly shed light on the mechanism explanation of environmental screening and seedling recruitment.

The major constraints of seedling recruitment depend on suitable habitats, sufficient temperature 
and length of growing season, adequate soil moisture and seed viability and availability and animal browsing as well (Sveinbjörnsson et al. 2002). Of which viable seeds are the basis and pivotal for tree establishment (Körner 2012). How seed germination and seedling recruitment respond to altitudes will likely be determined by seed quantity and quality and vary in slope aspects. Therefore, it is important to assess seed viability in response to environment change along altitudes in order to identify upper limit of tree establishment.

In this study, we assume that seed quantity and quality decrease dramatically at treeline ecotone. It will be the bottleneck of seedling recruitment source together with environmental filtering by harsh microclimate. To test this hypothesis, we measured seed quantity and quality, seedling recruitment and emergence and overwintering rate of transplanting seeds of smith fir in altitudinal gradient ranging from $3600 \mathrm{~m}$ in closed forests to $4400 \mathrm{~m}$ at treeline in the Sygera Mountains. The objectives are to: 1) measure change of seed quantity and quality and determine tipping point in the altitudinal gradient; 2) examine to which extent the seedling recruitment is constrained especially in treeline ecotone. Our study will underpin the foundation for the in-depth understanding of the formation mechanism of alpine treeline in southeastern Tibetan Plateau.

\section{Materials and Methods}

\subsection{Field sites and microclimate}

The study site is located in the Sygera
Mountains in southeastern Tibet, China $\left(29^{\circ} 37^{\prime}-\right.$ $29^{\circ} 41^{\prime} \quad \mathrm{N}$ and $94^{\circ} 39^{\prime}-92^{\circ} 47^{\prime} \mathrm{E}$, Figure 1), southward extension of the Nyenchenthanglha Mountains. The area is at the interface between humid and semi-humid climate zones in southeast Tibet. Affected by the Indian Ocean monsoon, the climate is characterized as "mild winter, cool summer, and distinct dry and wet seasons". According to the meteorological monitoring in Lynchi Forest Ecosystem Station at 3850 m a.s.l., mean annual air temperature (MAT) was $-0.7^{\circ} \mathrm{C}$. Warmest month (July) and coldest month (January) had an average temperature of $9.23^{\circ} \mathrm{C}$ and $-13.98^{\circ} \mathrm{C}$, respectively. The number of annual average sunshine hours was $1150.6 \mathrm{~h}$ with sunshine percentage of $26.1 \%$. Annual average precipitation was $936.1 \mathrm{~mm}$ and annual relative humidity is 78.83\% (Wang et al. 2005). The soil is composed mainly of thick layers of acid brown soil with distinct humification and $\mathrm{pH}$ of 4 to 6 (Yang et al. 2011). The mean annual soil temperature (MAST) at depth of $10 \mathrm{~cm}$ decreased to below zero at

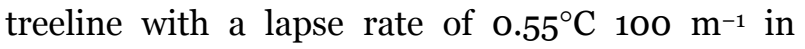
altitudinal gradient, while mean soil temperature in growing season declined mildly with lapse rate

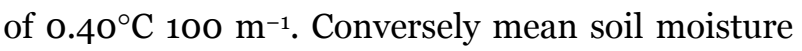
rose up with increasing altitude especially above $4000 \mathrm{~m}$ (Table 1).

The main vegetation in the Sygera Mountains is categorized as montane coniferous forests $(\mathrm{Li}$ and Han 1985) composed primary Abiesgeorgei var. smithii (smith fir), Picea likiangensis var. linzhiensis, and Juniperus saltuaria. Among them, smith fir and $J$. saltuaria can reach forest limit and form treelines. Smith fir dominates in north-facing slope and also occupies part of south-facing slope

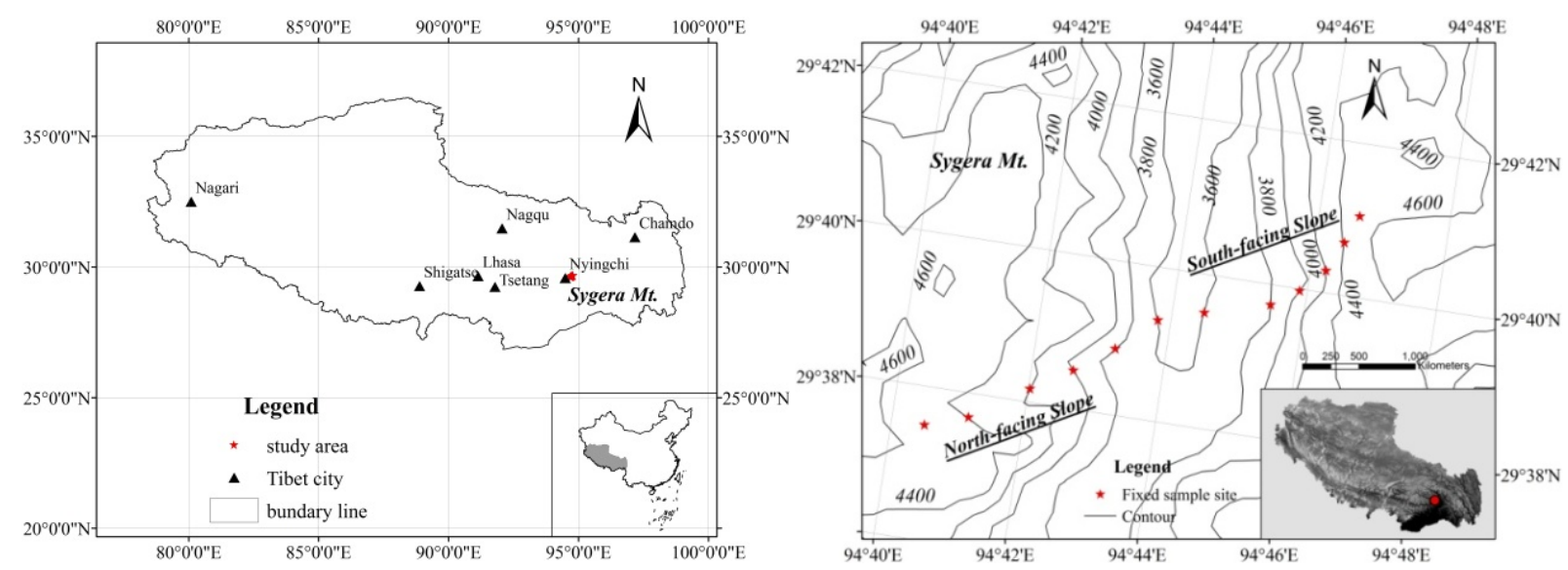

Figure 1 Location of the study area and the fixed sample sites. 
Table 1 Soil temperature and moisture at depth of $10 \mathrm{~cm}$ in different altitudes

\begin{tabular}{|c|c|c|c|c|c|c|c|c|c|c|c|c|c|c|c|c|}
\hline \multirow{2}{*}{$\begin{array}{l}\text { Altitude } \\
\text { (m) }\end{array}$} & \multicolumn{7}{|c|}{ Soil temperature in growing season $\left({ }^{\circ} \mathrm{C}\right)$} & \multicolumn{7}{|c|}{ Soil moisture in growing season (\%) } & \multirow{2}{*}{$\begin{array}{l}\text { MAST } \\
\left({ }^{\circ} \mathrm{C}\right)\end{array}$} & \multirow{2}{*}{$\begin{array}{l}\text { SM } \\
(\%)\end{array}$} \\
\hline & May & Jun & Jul & Aug & Sep & Oct & Mean & May & Jun & Jul & Aug & Set & Aug & Mean & & \\
\hline 3600 & 4.9 & $7 \cdot 7$ & 10.7 & 11.1 & 10.5 & 7.4 & 8.7 & 6 & 10 & 15 & 19 & 17 & 13 & 13 & 3.9 & 7 \\
\hline 3800 & 3.2 & 6.1 & 9 & & & $5 \cdot$ & $7 \cdot$ & 21 & 26 & & & & & & & 13 \\
\hline 4000 & 2.1 & $5 \cdot 7$ & 7.8 & 8. & $7 \cdot$ & 4.7 & 6.1 & 27 & 21 & 30 & $3:$ & 3 & 38 & 31 & 1.5 & 31 \\
\hline 4200 & 3.4 & 5.1 & 8.2 & 8.7 & $7 \cdot 4$ & 3.9 & 6.1 & 31 & 26 & 34 & 32 & 31 & 34 & 31 & 0.9 & 27 \\
\hline 4400 & 0.7 & 4.1 & 8.1 & 8.7 & 7.1 & 3.0 & $5 \cdot 3$ & 33 & 33 & 31 & 33 & 34 & 33 & 33 & -0.4 & 20 \\
\hline 4500 & 0.3 & 3.0 & 7.5 & 8.4 & 7.0 & 2.4 & 4.8 & 31 & 40 & 36 & 38 & 40 & 36 & 37 & -1.5 & 25 \\
\hline
\end{tabular}

Notes: MAST: mean annual soil temperature; SM: mean annual soil moisture.

to form treelines respectively (Zhang et al. 2010). Smith fir formed gradual treeline with group trees situated at $4370 \mathrm{~m}$ in both slopes according to the definition of Körner (1999). Treeline ecotones range from 4200 to $4400 \mathrm{~m}$. Above treeline some seedlings of smith fir can arrive at $4550 \mathrm{~m}$ but cannot establish trees. Shrubs dominated by Rhododendron nivale, $R$. lepidotum and take over alpine zone above treeline ( $\mathrm{Li}$ et al. 2009) together with Cassiope fastigiata, Potentilla fruticosa. The area above $4600 \mathrm{~m}$ is alpine meadow with sparse Kobresia spp., Saussurea spp., Corydalis spp., Saxifraga spp. and Rhodiola spp. (Wang et al. 2005). The altitudinal gradient ranging from 3800 to $4400 \mathrm{~m}$ dominated by smith fir in both sunny and shade slope of the Sygera Mountains provides ideal natural laboratory to examine performance of tree regeneration in contrast and changing environment (Yang et al. 2011; Zhang and Luo 2013).

The experimental sites are in the smith fir primary forests in the Sygera Mountains. Six $20 \times$ $30 \mathrm{~m}^{2}$ fixed sample sites were set up in northeastfacing slope and southwest-facing slope (hereafter referred to as north- and south-facing slope) respectively from 3600 to $4500 \mathrm{~m}$ (Figure 1). Altitudes of the sample sites had an interval of 200 $\mathrm{m}$, or $100 \mathrm{~m}$ above the treeline. Twelve sets of EM50 portable meteorological stations (Decagon, USA) were installed in closed forests of the 12 fixed sample sites at both north- and south-facing slope of the Sygera Mountains in May 2009, as indicated by the asterisks in Figure 1 to measure air temperature and humidity at $0.5 \mathrm{~m}$ above-ground as well as soil temperature and moisture at depth of $10,20,40$ and $60 \mathrm{~cm}$ layers. Seed rain, seed bank, germination and manipulation of transplanting seed emergence and overwintering experiments are monitored inside the fixed sample sites.
In the north-facing slope tree (with height higher than $150 \mathrm{~cm}$ ) density decreased gradually with increasing altitude. But densities of seedlings (height less than $20 \mathrm{~cm}$ ) and saplings (height between 20 and $150 \mathrm{~cm}$ ) dropped down sharply at treeline (Figure 2).

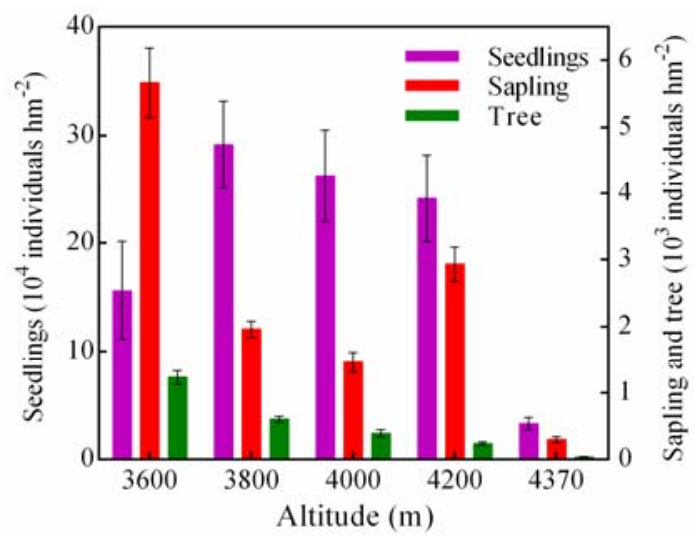

Figure 2 The numbers (mean \pm SE) of seedling, sapling and tree along altitudinal gradient in northfacing slope.

\subsection{Seed quality and quantity}

We measured and compared seed quantity, quality along altitudinal gradient in south- and north-facing slope, respectively. Seed quality is defined as the viability of seeds in terms of size, weight and germination rate (Kollas et al. 2012; Wilmking et al. 2012). Seed quantity is the production in terms of abundance or amount of seeds in per unit area. Seed quantity was measured as seed rain and seed bank density (Hofgaard 1993; Körner 2012) in this study.

Five to 10 pieces of smith fir cones in each altitude were collected in September 2008 and brought to laboratory for measurement. The cone volume was measured by submergence method and number of seeds per cone was recorded. Seed size was measured as seed volume by digital vernier 
caliper. Thousand kernel weight (TKW) was calculated as weight per 1000 seeds of over 300 seeds. Seed germination rate was measured as germination percentage of 100 seeds after incubation in wet filter paper at $25^{\circ} \mathrm{C}$ in the laboratory for one month until no sprout. The above parameters were measured with 5 replicates.

Seed rain was collected with five randomly distributed $100 \times 100 \mathrm{~cm}^{2}$ seed traps at each altitude site. The seed rain collector was made of wooden frame with dimension of $100 \mathrm{~cm}(\mathrm{~L}) \times 100$ $\mathrm{cm}(\mathrm{W}) \times 10 \mathrm{~cm}(\mathrm{H})$, and the bottom was covered by double-layer gauze net with $1 \times 1 \mathrm{~mm}^{2}$ mesh. Seed rain samples were collected in September and October in three years from 2008 to 2010.

Soil seed bank was measured with five $0.5 \times$ $0.5 \mathrm{~m}^{2}$ random-set sample quadrat. Soil collected to depth of $5 \mathrm{~cm}$ were brought and sieved in the laboratory. Soil seed bank density was calculated as the number per square meter of soil surface.

\subsection{Natural seedling recruitment}

In each fixed site along altitude, we set up ten randomly $1 \times 1 \mathrm{~m}^{2}$ sample quadrat to measure seedling recruitment including seedling density, age, basal diameter and height of seedlings less than five years. Age of trees was determined by counting all terminal bud scars from the apex to the base of the hypocotyls (Parent et al. 2000). Basal diameter was measure using vernier caliper. The mean values of above seedling parameters in each sample quadrat were calculated to represent the seedling recruitment at that altitude.

\subsection{Seedling emergence and survival}

To test in situ performance of seeds in the field, we collected seeds from 3600 and $3800 \mathrm{~m}$ in early winter 2008 to store in refrigerator at $5^{\circ} \mathrm{C}$. Viable seeds were selected by salt solution and air-dried before store in refrigerator. The average germination rate of viable seeds is $67 \%$, measured at constant temperature at $25^{\circ} \mathrm{C}$ in laboratory. Mixed viable seeds were sown to forest underground with similar canopy density in different altitudes in the north-facing slope in late June 2009. In each altitude, we sowed 100 seeds in $1 \mathrm{~m} \times 1 \mathrm{~m}$ quadrat with three replicates. To prevent the seed rain of the previous year from falling into the sowing quadrat and animal browsing, each quadrat was shielded by gauze net in fall of 2008, and the germinated seedlings before seed transplanting experiment were eliminated. The emergence of seedling was recorded in every half month during the growing season from June to October in 2009. The number of seeds emerging was summarized to calculate seedling emergence rate. Seedling survival in the sowing quadrat was examined in late June 2010 as seed overwintering rate.

\subsection{Statistical analysis}

All data were converted to standard units and plotted using mean and standard error (SE). To test difference of seed quantity and quality, seedling recruitment and emergence rate along altitudinal sites, a repeated one-way analysis of variance (ANOVA) was used. When the ANOVA results were significant, means were compared using the least significant difference (LSD) test. All statistical analyses were performed using SPSS version 20.0 (SPSS Inc., IL, USA) and figures were drawn using GraphPad Prism version 6.0 (GraphPad Software Inc., CA, USA).

\section{Results}

\subsection{Seed quantity-seed rain and soil seed bank}

Seed production, in terms of seed rain density varied yearly. Seed mast years occurred in 2009 and 2010 respectively in south- and north-facing slope of the Sygera Mountains (Figure 3). At same altitude from 3600 to $4400 \mathrm{~m}$, average seed rain densities of smith fir were roughly the same at north- and south-facing slope (Figure $3 \mathrm{a}$ and $3 \mathrm{~b}$ ). Quantitatively large difference occurred among altitudes. In average, seed rain density showed rapid decrease at altitudes higher than $4000 \mathrm{~m}$ $(p<0.05)$. It is indicated that seed yields were mainly produced at altitudes less than $4000 \mathrm{~m}$. At treelines, densities of seed rain in both slopes were scarce.

Seed bank also showed significantly decrease from 3800 to $4400 \mathrm{~m}$ in both slopes. It appeared that seed bank density had a peak at $3800 \mathrm{~m}$ 
(a)

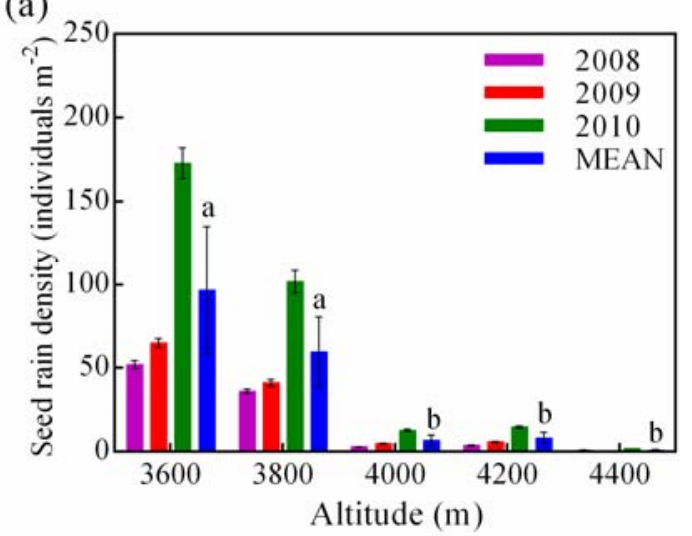

(b)

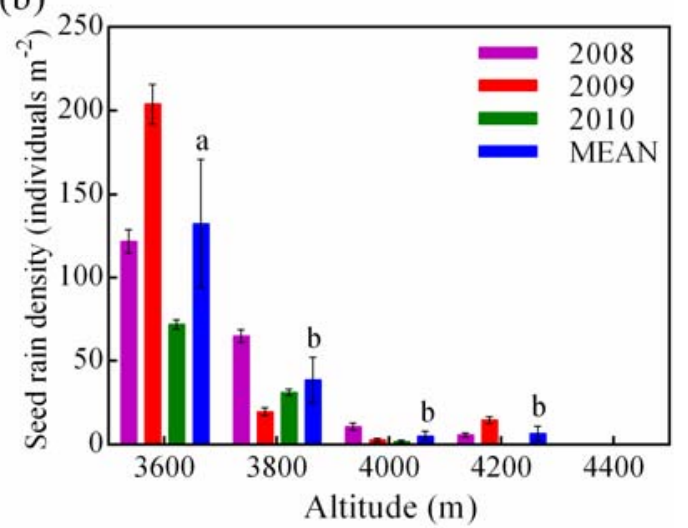

Figure 3 Seed rain density at the altitude gradient of the north-facing slope (a) and south-facing slope (b). MEAN is the average seed rain from 2008 to 2010. Bars represent standard error of the mean in 2008 to $2010(n=5)$. Significant differences $(p<0.05)$ between the means $( \pm$ SE) are marked with different lowercase letters at different altitudes.

although it was higher in north-facing slope than in south-facing slope (Figure 4). At treeline, seed density was reduced to $8.9 \%$ of that in $3800 \mathrm{~m}$ in north-facing slope. There were no seeds at treeline seed bank in south-facing slope. Despite its highest seed production, sites at $3600 \mathrm{~m}$ had lower seed density in seed bank (Figure 3 and Figure 4).

\subsection{Seed quality and germination}

Seed quality and germination characteristics of smith fir at different altitudes are shown in Table 2. Although cone size (cone volume) decreased slightly along the altitudinal gradients, other parameters of seed quality showed rapid decrease, especially TKW and seed germination rate (SGR). Compared with at $3600 \mathrm{~m}$, the cone volume, number of seeds per cone, seed volume and thousand kernel weight were reduced by $39.75 \%$, $33.67 \%, 64.29 \%$ and $83.06 \%$ respectively at treeline in $4400 \mathrm{~m}$, indicating that seed quality decreased sharply especially at treeline. Poor seed quality resulted in very low germination rate at treeline. These findings indicate that seed quality is a decisive factor that limits recruitment at treeline.

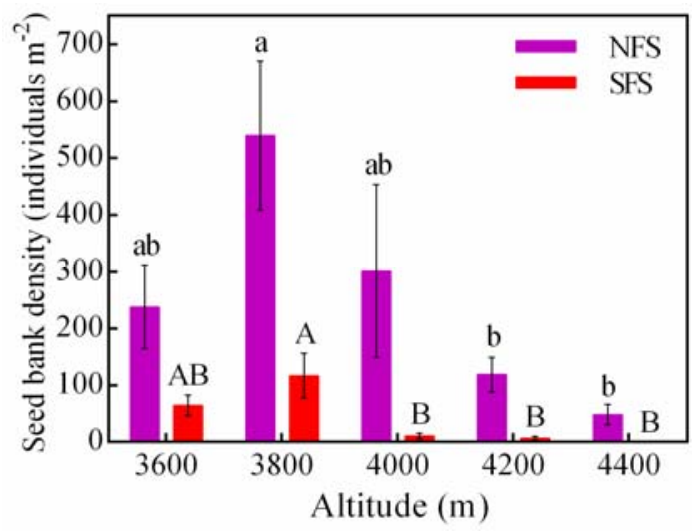

Figure 4 Change of soil seed bank densities at north-facing slope (NFS) and south-facing slope (SFS) with increasing altitude. Significant differences $(p<0.05)$ between the means $( \pm \mathrm{SE})$ are marked with different letters (lowercase for north-facing slope and uppercase for south-facing slope) at different altitudes $(n=5)$.

Table 2 Characteristics of conifer cone, seeds and germination rate at different altitudes

\begin{tabular}{|l|l|l|l|l|l|}
\hline $\begin{array}{l}\text { Altitude } \\
(\mathrm{m})\end{array}$ & $\begin{array}{l}\text { Cone volume } \\
\left(\mathrm{cm}^{3}\right)\end{array}$ & $\begin{array}{l}\text { Number of seeds } \\
\text { per cone }(\mathrm{n})\end{array}$ & $\begin{array}{l}\text { Seed volume } \\
\left(\mathrm{cm}^{3}\right)\end{array}$ & $\begin{array}{l}1000 \text {-kernel weight } \\
(\mathrm{g})\end{array}$ & $\begin{array}{l}\text { Seed germination } \\
\text { rate }(\%)\end{array}$ \\
\hline 3600 & $65.13 \pm 7.00^{\mathrm{a}}$ & $502 \pm 21^{\mathrm{a}}$ & $0.42 \pm 0.02^{\mathrm{a}}$ & $1.83 \pm 0.05^{\mathrm{a}}$ & $78 \pm 6^{\mathrm{a}}$ \\
\hline 3800 & $54.79 \pm 4.56^{\mathrm{ab}}$ & $412 \pm 16^{\mathrm{b}}$ & $0.30 \pm 0.01^{\mathrm{b}}$ & $1.02 \pm 0.01^{\mathrm{b}}$ & $56 \pm 5^{\mathrm{b}}$ \\
\hline 4000 & $58.90 \pm 5.49^{\mathrm{a}}$ & $454 \pm 18^{\mathrm{ab}}$ & $0.26 \pm 0.02^{\mathrm{b}}$ & $1.11 \pm 0.03^{\mathrm{c}}$ & $37 \pm 2^{\mathrm{c}}$ \\
\hline 4200 & $51.64 \pm 4.69^{\mathrm{ab}}$ & $416 \pm 14^{\mathrm{b}}$ & $0.18 \pm 0.01^{\mathrm{c}}$ & $0.92 \pm 0.01^{\mathrm{d}}$ & $16 \pm 2^{\mathrm{d}}$ \\
\hline 4400 & $39.24 \pm 1.32^{\mathrm{b}}$ & $333 \pm 13^{\mathrm{c}}$ & $0.15 \pm 0.02^{\mathrm{c}}$ & $0.81 \pm 0.01^{\mathrm{e}}$ & $3 \pm 1^{\mathrm{e}}$ \\
\hline 4500 & - & - & - & - & -
\end{tabular}

Notes: Values (mean \pm SE) within the same column followed by the different lowercase letters are significantly different $(p<0.05)$ among different altitudes respectively according to LSD test. 


\subsection{Natural seedling recruitment}

The recent seedling recruitment $(<5$ years $)$ in terms of seedling density varied in different slope aspects, generally with higher density in northfacing slope than in south-facing slope at the same altitude. Seedling recruitment reached peaks at altitude of 4000 and $3600 \mathrm{~m}$ respectively in northand south-facing slope. Seedling density presented cliff-like drop in treeline ecotone from 4200 to 4400 $\mathrm{m}$ in north-facing slope, while went down significantly but gently from $3800 \mathrm{~m}$ in south-facing slope. At treeline in both slopes there was almost no seedling recruitment (Table 3). Other seedling traits presented irregularly spatial patterns.

\subsection{Seedling emergence and survival}

Along altitudinal gradient in north-facing slope, seedling emergence rate (SER) decreased by $55 \%$ from $87 \%$ at $3600 \mathrm{~m}$ to $32 \%$ at treeline. Above treeline at $4500 \mathrm{~m}$ the emergence rate went down to nearly $20 \%$. Average SER dropped sharply from $82.8 \%$ in closed forest below $4200 \mathrm{~m}$ to $28.0 \%$ in treeline ecotone. Seedling overwinter rate (SOR) also showed rapidly decrease at treeline ecotone, with average SOR ranging from $9.6 \%$ in closed forest to $3.3 \%$ at treeline (Table 4 ). The results suggest transplanted viable seeds of closed forests from 3600 to $3800 \mathrm{~m}$ emerge significantly lower at treeline ecotone than original habitats.

With joint analysis of natural seedling recruitment, transplanting seed emergence and microclimate (Table 1 and Table 4) along altitudinal gradient, it is clear that treeline ecotone from 4200 to $4400 \mathrm{~m}$ is the critical area for seedling recruitment and overwintering. For

Table 3 Characteristics of seedlings at different altitudes and slope aspects

\begin{tabular}{|c|c|c|c|c|c|}
\hline Slope aspect & Altitude (m) & $\begin{array}{l}\text { Seedling density } \\
\text { (individuals } \mathrm{m}^{-2} \text { ) }\end{array}$ & Average age (a) & $\begin{array}{l}\text { Basal diameter } \\
(\mathrm{cm})\end{array}$ & $\begin{array}{l}\text { Mean height } \\
(\mathrm{cm})\end{array}$ \\
\hline \multirow{6}{*}{ North-facing slope } & 3600 & $1.66 \pm 0.23^{\mathrm{a}}$ & $3.06 \pm 0.29^{a}$ & $0.13 \pm 0.02^{\mathrm{a}}$ & $4.03 \pm 0.58^{a}$ \\
\hline & 3800 & $13.87 \pm 3.32^{b}$ & $2.5^{2} \pm 0.19^{a}$ & $0.12 \pm 0.01^{\mathrm{a}}$ & $2.92 \pm 0.44^{\mathrm{ab}}$ \\
\hline & 4000 & $17 \cdot 33 \pm 5.78^{b}$ & $2.18 \pm 0.18^{a}$ & $0.12 \pm 0.01^{\mathrm{a}}$ & $2.13 \pm 0.19^{b c}$ \\
\hline & 4200 & $12.30 \pm 2.95^{\mathrm{b}}$ & $3.20 \pm 0.73^{a}$ & $0.14 \pm 0.02^{a}$ & $3.75 \pm 0.67^{\mathrm{ab}}$ \\
\hline & 4400 & $0.30 \pm 0.01^{a}$ & $5.10 \pm 0.35^{b}$ & $0.21 \pm 0.02^{b}$ & $6.43 \pm 0.87^{d}$ \\
\hline & 4500 & - & - & - & - \\
\hline \multirow{6}{*}{ South-facing slope } & 3600 & $9.80 \pm 2.85^{\mathrm{a}}$ & $4.26 \pm 0.46^{a}$ & $0.17 \pm 0.01^{a}$ & $4.20 \pm 0.5^{\mathrm{a}}$ \\
\hline & 3800 & $2.74 \pm 0.55^{\mathrm{ab}}$ & $3.29 \pm 0.63^{\mathrm{a}}$ & $0.16 \pm 0.03^{\mathrm{ab}}$ & $3.55 \pm 0.78^{a}$ \\
\hline & 4000 & $1.50 \pm 0.10^{c}$ & $1.40 \pm 0.40^{\mathrm{b}}$ & $0.10 \pm 0.01^{b c}$ & $1.25 \pm 0.25^{\mathrm{b}}$ \\
\hline & 4200 & $1.33 \pm 0.33^{c}$ & $1.00 \pm 0.01^{b}$ & $0.10 \pm 0.01^{b}$ & $1.00 \pm 0.06^{b}$ \\
\hline & 4400 & - & - & - & - \\
\hline & 4500 & - & - & - & - \\
\hline
\end{tabular}

Notes: Values (mean \pm se) within the same column followed by the different lowercase letters are significantly different $(p<0.05)$ among different altitudes at north- and south-facing slope respectively according to LSD test ( $\mathrm{n}=$ 10).

Table 4 Seed emergence rate and overwintering rate of seedlings in different altitudes

\begin{tabular}{|c|c|c|c|c|c|c|c|c|}
\hline Altitude (m) & SER (\%) & SOR (\%) & MSH (\%) & $\operatorname{DAT}(\mathrm{d})$ & ELAT $\left({ }^{\circ} \mathrm{C}\right)$ & $\operatorname{ATGS}\left({ }^{\circ} \mathrm{C}\right)$ & ATo $\left({ }^{\circ} \mathrm{C}\right)$ & $\mathrm{AT} 5\left({ }^{\circ} \mathrm{C}\right)$ \\
\hline 3600 & $87 \pm 5^{\mathrm{a}}$ & $10.4 \pm 0.8^{a}$ & 1 & 269 & -10.0 & 10.7 & 1873 & 753 \\
\hline 3800 & $85 \pm 4^{a}$ & $9.5 \pm 0.6^{\mathrm{a}}$ & 3 & 233 & -9.6 & 9.7 & 1513 & 569 \\
\hline 4000 & $80 \pm 5^{a}$ & $11.0 \pm 1.2^{\mathrm{ab}}$ & 21 & 218 & -9.9 & 8.0 & 1298 & 451 \\
\hline 4200 & $79 \pm 6^{a}$ & $7.6 \pm 0.8^{b}$ & 12 & 203 & -12.4 & 8.3 & 1142 & 355 \\
\hline 4400 & $32 \pm 4^{b}$ & $3.3 \pm 0.5^{c}$ & 1 & 189 & -15.7 & $7 \cdot 3$ & 978 & 264 \\
\hline 4430 & $30 \pm 3^{b}$ & $0.9 \pm 0.9^{c}$ & - & 186 & - & 6.7 & 939 & 236 \\
\hline 4450 & $27 \pm 4^{b}$ & o & - & 185 & - & 6.6 & 904 & 211 \\
\hline 4500 & $23 \pm 1^{b}$ & o & 7 & 181 & -15.8 & $5 \cdot 9$ & 830 & 159 \\
\hline
\end{tabular}

Notes: Values (mean \pm SE) within the same column followed by the different lowercase letters are significantly different $(p<0.05)$ among different altitudes according to LSD test $(n=3)$. SER: seedling emergence rate; SOR: seedling overwintering rate; $\mathrm{MSH}$ : minimum soil moisture at soil depth of $10 \mathrm{~cm}$; DAT: days of air temperature $>0^{\circ} \mathrm{C}$; ELAT: extreme low air temperature; ATGS: air temperature during growing season; ATo: $>\mathrm{O}^{\circ} \mathrm{C}$ accumulated temperature; $\mathrm{AT}_{5}:>5^{\circ} \mathrm{C}$ accumulated temperature. 
successful recruitment, suitable soil temperature at $10 \mathrm{~cm}$ is over $6^{\circ} \mathrm{C}$ in growing season, mean annual soil temperature above $0^{\circ} \mathrm{C}$ (Table 1). And other beneficial heat conditions are length of growing season with air temperature above $0^{\circ} \mathrm{C}$ more than 200 days, mean air temperature higher than $8^{\circ} \mathrm{C}$, accumulated temperature $>0^{\circ} \mathrm{C}$ and $5^{\circ} \mathrm{C}$ exceeding $1000^{\circ} \mathrm{C}$ and $300^{\circ} \mathrm{C}$, respectively (Table 4 ).

\section{Discussion}

This altitudinal survey of seed and seedling traits revealed sharp reduction of seed quantity and quality, and consequently constrained seedling recruitment at treeline ecotone. Thus our results support our hypothesis that seed quantity and quality are critical bottleneck for tree establishment and advancement at treeline ecotone, matching the observation of no change treeline position in past 200 years in the Sygera Mountains.

\subsection{Seed quantity and quality}

Our results of seed rain, soil seed bank and seed quality of smith fir decreased with the increase in altitude, consistent with the conclusion of most seed ecology studies in world treeline ecotone (Wardle 1970; Black and Bliss 1980; Allen and Platt 1990; Szeicz and Macdonald 1995; Cuevas 2000).

Seed quantity decreased sharply 200 to $400 \mathrm{~m}$ below treeline, specifically seed rain decreased rapidly in lower elevation at $4000 \mathrm{~m}$, while seed bank dropped down at $4200 \mathrm{~m}$. Similar rapid decrease of seed quantity and quality was also observed over the last $200 \mathrm{~m}$ below treeline of Picea abies (see Körner 2012) in Swiss Alps and treeline of Betula pubescens ssp. tortuosa in northern Sweden (Molau and Larsson 2000). This change was associated with sparse and sharp decrease of tree density (Figure 2) and seed production (Figure 3) at treeline ecotone. Other reasons might include long interval of mast seed year, short length of growing season and multi-year duration of conifer cone maturation at treeline (Körner 2012).

Seeds become mature, fall to the soil and then enter seed bank if they cannot germinate within a short period (Walck et al. 2011). Seed bank can be balanced by germination, aging, death, or animal grazing (Kudo and Hirao 2006; Turner et al. 2006; Wagner and Mitschunas 2008; Inouye 2008). The reasons why seed bank densities apparently higher at north-facing slope than at south-facing slope depended on lower soil temperature, close canopy and shade environment, and consequently leading to lower seed germination in north-facing slope. Soil seed bank plays a potential important role in vegetation regeneration (Szwagrzyk et al. 2001) and population stabilization (Silva and Tabarelli 2001). Sharp decline of seed bank density in treeline ecotone ranging from 4200 to $4400 \mathrm{~m}$ suggests that the balance of seed population will potentially become regeneration bottleneck in this area.

Germination rates of seeds in different altitudes in same condition of laboratory provided direct evidence of seed quality. Seed germination rate in laboratory is only $3 \%$. The apparent fall of seed quality is associated closely with smaller seed size and lower thousand kernel weight at treeline ecotone. Low seed quality could be resulted from the constraints imposed by low temperature and short length of growing season (Sveinbjörnsson et al. 1996). Similar decrease of seed quality is also found in some survey (Tranquillini 1979). But seed size and size of embryos are conservative traits. There is little change of seed quality in terms of seed size (Körner 2012). Kollas et al. (2012) found tree seed quality did not reduce in high elevation range limit. Some species, for example Polylepis incana in Ecuador (Marcora et al. 2008) and Betula pubescens in north Sweden (Holm 1994) even increase seed weight with elevation. Körner (2012) speculated that a resource limitation-driven selection could be based on the tradeoff between seed size and total number of seed production. In contrast to closed forest, sparse trees at treeline would be expected to select bigger seeds, enhancing seedling survival. Unfortunately we found decline in both seed quantity and quality in the Sygera Mountains. This might worsen seedling recruitment, and thereby become bottleneck for tree establishment at treeline ecotone.

\subsection{Seedling recruitment and survival}

It is clear from our data to reveal that seed size and seed quantity both affected germination, seedling recruitment and survival. First, small and 
light seeds at treeline ecotone have limited nutrient reserves, unable to develop extensive root systems. Seedlings would be inferior to adaptation in the harsh, variable environment (Cuevas 2000). Second, relatively seed rain density decreased more sharply than seed size and mass (Figure 3 and Table 2), indicating seed traits more conservative in seed size than seed number. As a result, seed quantity becomes the more severe bottleneck for seedling recruitment.

Despite all that, there were relatively mild changes in seed traits but sharp fall of germination, seedling density, and emergence and overwintering rate of transplanted seeds at treeline ecotone. This indicates that seed traits therefore appeared to be less important than harsh microclimate in determining seedling recruitment. Apart from other thermal thresholds for successful recruitment, suitable soil temperature at $10 \mathrm{~cm}$ over $6{ }^{\circ} \mathrm{C}$ in growing season is consistent with the temperature threshold of plant starting growth and world treeline (Körner and Paulsen 2004).

Climate has a critical influence on seedling recruitment. Particularly, the influence of temperature and moisture on seed dormancy, germination, seedling growth and the survival determines whether regeneration can be successful (Fitch et al. 2007; Walck and Dixon 2009; Baeten et al. 2010). The change in altitude often triggers the change in temperature and moisture conditions. In an environment with adequate moisture alike at treeline, temperature plays a decisive role in the germination of seeds and the growth and development of seedlings. Studies have shown that harsh habitat conditions (i.e., abiotic factors) in a high-altitude region affect the carbon balance of individual seedlings, and reduced carbon balance due to the increase in altitude not only shortens the growth season (Tranquillini 1979; Stevens and Fox 1991) but also weakens the net photosynthesis rate (Körner 1998). But ultimately low temperature limits seedling growth rather than carbon source (Korner 2003). The low temperature at high altitudes affects the storage of energy by residual seedlings and results in seedlings more sensitive to environmental pressure. This indirect influence will more easily cause the damage or death of individuals than direct influence (Cuevas 2000). The results of the study indicated that along with increase in altitude, temperature is the most severe bottleneck in seed germination, seedling emergence and survival.

Harsh microclimate has important role in environment filtering so that emergence and overwintering rate are fairly low. Hofgaard (1993) monitored nearly 10 years of seed rain quantity and quality and found seed viability did not exceed $1 \%$ in northern Sweden. The mortality of emerged seedlings is reported to be very high in the first year (Ohlson and Zackrisson 1992), consistent with our observation. Although we did not know regeneration history and periodic seed production, we can simply calculate the turnover rate of seedlings to saplings and trees using data of Figure 2. The mean turnover rate of seedlings to saplings and saplings to trees is $1.4 \%$ and $20 \%$ respectively in altitudinal gradient, but the rates drop to $0.9 \%$ and $8.2 \%$ respectively at treeline. Despite very sparse recruitment in most years, continuous years of low regeneration are short in comparison with long life history of trees. Consequently periodic regeneration success in benign years is sufficient for maintenance of treeline position (Hofgaard 1993).

Taken together, this study suggests that harsh environment especially low temperature is the overwhelming controller and threshold to constrain tree recruitment at treeline ecotone. However, our results are based on short period of survey. Detailed eco-physiological studies are required to examine how dynamics of seedling fate, role of environmental filtering and tree establishment contribute to treeline dynamics.

\section{Conclusion}

Our results show that seed quantity and quality are bottleneck of seedling recruitment at treeline ecotone. Low temperature is the overwhelming controller of treeline dynamics. Seedling recruitment in early stage constrains treeline advancement, and thereby maintains stable treeline position in southeastern Tibetan Plateau.

\section{Acknowledgements}

This workwas supported by the foundations of Special Research Program for Public-welfare Forestry (Grant No. 200804001), Tibet Plateau 
Ecological Safety Barrier Monitor Evaluation Method and Technology Research (Grant No. KZCX2-XB3-08), and Strategic Priority Research Program of the Chinese Academy of Sciences (Grant No. XDA05090311). We sincerely appreciate the valuable advices proposed by the anonymous reviewers. We thank the ecology discipline team in Renmin University of China for providing meteorological monitoring equipment and field experiment base. Thanks are also extended to Prof. PU Qiong (Tibetan), Prof. LUO Da-qing and Prof. PAN Gang from Research Center of Tibet Plateau Ecology in Tibet Agriculture and Animal Husbandry College for providing help of experiment settings and field work.

\section{References}

Allen RB, Platt K (1990) Annual seedfall variation in Nothofagus solandri (Fagaceae), Canterbury, New Zealand. Oikos 57(57): 199-206. DOI: $10.2307 / 3565940$

Baeten L, De Frenne P, Verheyen K, et al. (2010) Forest herbs in the face of global change: a single-species-multiple-threats approach for Anemone nemorosa. Plant Ecology and Evolution 143(1): 19-30. DOI: 10.5091/plecevo.2010.414

Black RA, Bliss L (1980) Reproductive ecology of Picea mariana (Mill.) BSP., at tree line near Inuvik, Northwest Territories, Canada. Ecological Monographs 5O(3): 331-354. DOI: $10.2307 / 2937255$

Clark JS (1998) Why trees migrate so fast: Confronting theory with dispersal biology and the paleorecord.American Naturalist 152(2):204-224. DOI: $10.1086 / 286162$

Cuevas JG (2000) Tree recruitment at the Nothofagus pumilio alpine timberline in Tierra del Fuego Chile. Jornal of Ecology 88(5):840-855. DOI: 10.1046/j.1365-2745.2000.00497.x

Fitch EA, Walck JL, Hidayati SN (2007) Agroecosystem management for rare species of Paysonia (Brassicaceae): integrating their seed ecology and life cycle with cropping regimens in a changing climate. American Journal of Botany 94(1):102-110. DOI: 10.3732/ajb.94.1.102

Hoch G, Korner C (2005) Growth, demography and carbon relations of Polylepis trees at the world's highest treeline. Functional Ecology 19(6): 941-951. DOI: 10.1111/j.1365-2435. 2005.01040.X

Hofgaard A (1993) Seed rain quantity and quality, 1984-1992, in a high altitude old-growth spruce forest, northern Sweden. New Phytologist 125(3): 635-640.DOI: 10.1111/j.1469-8137. 1993.tbo3913.x

Holm SO (1994) Reproductive variability and pollen limitation in three Betula taxa in northern Sweden. Ecography 17: 73-81. DOI: 10.1111/j.1600-0587.1994.tboo078.x

Holtmeier F (2005) Change in the timberline ecotone in northern Finnish Lapland during the last thirty years. Reports from the Kevo Subarctic Research Station 23:97-113.

Holtmeier FK, Broll G, Müterthies A, et al. (2003) Regeneration of trees in the treeline ecotone: northern Finnish Lapland. Fennia 181(2): 103-128.

Inouye DW (2008) Effects of climate change on phenology, frost damage, and floral abundance of montane wildflowers. Ecology 89(2): 353-362. DOI: 10.1890/06-2128.1

Kollas C, Vitasse Y, Randin CF, et al. (2012) Unrestricted quality of seeds in European broad-leaved tree species growing at the cold boundary of their distribution. Annals of Botany 109(2): 473-480. DOI: 10.1093/aob/mcr299

Körner C (1998) A re-assessment of high elevation treeline positions and their explanation. Oecologia 115(4): 445-459. DOI: $10.1007 /$ soo4420050540

Korner C(1999) Alpine plants: stressed or adapted? In: Press MC, Scholes JD, Barker MG (eds.), Physiological Plant Ecology. Blackwell Science Publ, Oxford, UK. pp 297-311.
Korner C (2003) Carbon limitation in trees. Journal of Ecology 91(1): 4-17. DOI: 10.1046/j.1365-2745.2003.00742.x

Körner C (2012) Alpine treelines - functional ecology of the global high elevation tree limits. Springer, Basel, Switzerland. DOI: 10.1007/978-3-0348-0396-o

Körner C, Paulsen J (2004) A world wide study of high altitude treeline temperatures. Journal of Biogeography 31(5): 713-731. Kudo G, Hirao AS (2006) Habitat-specific responses in the flowering phenology and seed set of alpine plants to climate variation: implications for global-change impacts. Population Ecology 48(1): 49-58. DOI: 10.1007/s10144-005-0242-Z

Li MC, Kong GQ, Zhu JJ (2009) Vertical and leaf-age-related variations of nonstructural carbohydrates in two alpine timberline species, southeastern Tibetan Plateau. Journal of Forest Research 14(4): 229-235. DOI:10.1007/s10310-0090132-X

Li MH, Xiao WF, Wang SG, et al. (2008) Mobile carbohydrates in Himalayan treeline trees I. Evidence for carbon gain limitation but not for growth limitation. Tree physiology 28(8): 1287-1296.

Li W, Han Y (1985) Forests of Xizang. Science Press, Beijing, China. pp 375. (In Chinese)

Liang EY, Wang YF, Eckstein D, et al. (2011) Little change in the fir tree-line position on the southeastern Tibetan Plateau after 200 years of warming. New Phytologist 190(3): 760-769. DOI: 10.1111/j.1469-8137.2010.03623.x

Liu B, Liang EY, Zhu LP (2011) Microclimatic conditions for Juniperus saltuaria treeline in the Sygera Mountains, Southeastern Tibetan Plateau. Mountain Research and Development 31(1): 45-53. DOI: 10.1659/MRD-JOURNAL-D10-00096.1

Liu XS, Luo TX (2011) Spatiotemporal variability of soil temperature and moisture across two contrasting timberline ecotones in the Sergyemla Mountains, Southeast Tibet. Arctic, Antarctic, and Alpine Research 43(2): 229-238. DOI: 10.1657/ 1938-4246-43.2.229

Lloyd AH, Fastie CL (2002) Spatial and temporal variability in the growth and climate response of treeline trees in Alaska. Climatic Change 52(4):481-509. DOI: 10.1023/a:1014278819 094

MacDonald GM, Szeicz JM, Claricoates J, et al. (1998) Response of the central Canadian treeline to recent climatic changes. Annals of the Association of American Geographers 88(2): 183-208. DOI: 10.1111/1467-8306.00090

Maher E, Germino MJ, Hasselquist NJ (2005) Interactive effects of tree and herb cover on survivorship, physiology, and microclimate of conifer seedlings at the alpine-treeline ecotone. Canadian Journal of Forest Research 35(3): 567-574. DOI: 10.1139/Xo4-201

Maher EL, Germino MJ (2006) Microsite differentiation among conifer species during seedling establishment at alpine treeline. Ecoscience 13(3): 334-341. DOI: 10.2980/i11956860-13-3-334.1 
Malanson GP (2001) Complex responses to global change at alpine treeline. Physical Geography 22(4):333-342. DOI: 10.1080/02723646.2001.10642747

Marcora P, Hensen I, Renison D, et al. (2008) The performance of Polylepis australis trees along their entire altitudinal range: implications of climate change for their conservation. Diversity and Distributions 14(4): 630-636. DOI: 10.1111/ j.1472-4642.2007.00455.x

Miehe G, Miehe S, Vogel J (2007) Highest treeline in the Northern Hemisphere found in Southern Tibet. Mountain Research and Development 27(2): 169-173. DOI: 10.1659/ mrd.0792

Molau U, Larsson EL (2000) Seed rain and seed bank along an alpine altitudinal gradient in Swedish Lapland. Canadian Journal of Botany 78(6): 728-747.

Ohlson M, Zackrisson O (1992) Tree establishment and microhabitat relationships in north Swedish peatlands. Canadian Journal of Forest Research 22(12): 1869-1877.

Parent S, Morin H, Messier C (2000) Effects of adventitious roots on age determination in Balsam fir (Abies balsamea) regeneration. Canadian Journal of Forest Research 30(3): 513-518.

Peters DPC (2002) Plant species dominance at a grasslandshrubland ecotone: an individual-based gap dynamics model of herbaceous and woody species. Ecological Modelling 152(1): 5-32. DOI: $10.1016 /$ so304-380o(01)00460-4

Press MC, Potter JA, Burke MJW, et al. (1998) Responses of a subarctic dwarf shrub heath community to simulated environmental change. Journal of Ecology 86(2): 315-327. DOI: 10.1046/j.1365-2745.1998.00261.x

Shen W, Zhang L, Liu XS, et al. (2014) Seed-based treeline seedlings are vulnerable to freezing events in the early growing season under a warmer climate: Evidence from a reciprocal transplant experiment in the Sergyemla Mountains, southeast Tibet. Agricultural and Forest Meteorology 187(8): 83-92. DOI: 10.1016/j.agrformet.2013.12.004

Shi PL, Koerner C, Hoch G (2008) A test of the growthlimitation theory for alpine tree line formation in evergreen and deciduous taxa of the eastern Himalayas. Functional Ecology 22(2): 213-220.DOI: 10.1111/j.1365-2435.2007.01370. $\mathrm{x}$

Silva MG, Tabarelli M (2001) Seed dispersal, plant recruitment and spatial distribution of Bactris acanthocarpaMartius (Arecaceae) in a remnant of Atlantic forest in northeast Brazil. Acta Oecologica 22(5): 259-268. DOI: 10.1016/s1146-609x(01) 01117-1

Smith WK, Germino MJ, Hancock TE, et al. (2003) Another perspective on altitudinal limits of alpine timberlines. Tree physiology 23(16): 1101-1112.

Smith WK, Germino MJ, Johnson DM, et al. (2009) The altitude of alpine treeline: A bellwether of climate change effects. Botanical Review 75(2): 163-190. DOI: 10.1007/ s12229-009-9030-3

Stevens GC, Fox JF (1991) The causes of treeline. Annual review of ecology and systematics 22(1): 177-191. DOI: 10.1146/ annurev.ecolsys.22.1.177

Sveinbjörnsson B, Hofgaard A, Lloyd A (2002) Natural causes of the tundra-taiga boundary. Ambio (Special 12): 23-29.

Sveinbjörnsson B, Kauhanen H, Nordell O (1996) Treeline ecology of mountain birch in the Torneträsk Area. Ecological Bulletins 45: 65-70.

Szeicz JM, Macdonald GM (1995) Recent white spruce dynamics at the subarctic alpine treeline of north-western Canada. Journal of Ecology 83(5): 873-885

Szwagrzyk J, Szewczyk J, Bodziarczyk J (2001) Dynamics of seedling banks in beech forest: results of a 10-year study on germination, growth and survival. Forest Ecology and Management 141(3): 237-250. DOI: 10.1016/so378-1127(oo) 00332-7

Theurillat JP, Guisan A (2001) Potential impact of climate change on vegetation in the European Alps: Areview. Climatic change 5o(1-2): 77-109. DOI: 10.1023/a:1010632015572

Tranquillini W (1979) Physiological ecology of the alpine timberline: Tree existence at high altitudes with special reference to the European Alps. Springer-Verlag, Berlin, Germany. p 137.

Turner S, Merritt D, Ridley E, et al. (2006) Ecophysiology of seed dormancy in the Australian endemic species Acanthocarpus preissii (Dasypogonaceae). Annals of Botany 98(6): 1137-1144. DOI: $10.1093 / \mathrm{aob} / \mathrm{mcl} 203$

Wagner M, Mitschunas N (2008) Fungal effects on seed bank persistence and potential applications in weed biocontrol: A review. Basic and Applied Ecology 9(3): 191-203. DOI: 10.1016/j.baae.2007.02.003

Walck J, Dixon K (2009) Time to future-proof plants in storage. Nature 462(7274): 721. DOI: 10.1038/462721a

Walck JL, Hidayati SN, Dixon KW, et al. (2011) Climate change and plant regeneration from seed. Global Change Biology 17 (6): 2145-2161. DOI:10.1111/j.1365-2486.2010.02368.x

Wang JS, Wang WB, Pu Q (2005) Soil hydrological functions of the main forests on Sejila hills in Tibet. Journal of Northeast Forestry University 33(2): 48-51. DOI: 10.13759/j.cnki.dlxb. 2005.02.020 (In Chinese)

Wang XP, Zhang L, Fang JY (2004) Geographical differences in alpine timberline and its climatic interpretation in China. Acta Geographica Sinica 59(6): 871-879. DOI: 10.3321/j.issn: 0375-5444.2004.06.009 (In Chinese)

Wardle J (1970) The ecology of nothofagus solandri: 4. Growth, and general discussion to parts 1-4. New Zealand journal of botany 8(4): 609-646.

Wilmking M, Sanders TGM, Zhang Y, et al. (2012) Effects of climate, site conditions, and seed quality on recent treeline dynamics in NW Russia: Permafrost and lack of reproductive success hamper treeline advance? Ecosystems 15(7): 10531064. DOI: 10.1007/s10021-012-9565-8

Yang XL, Wang JS, Chen BX, et al. (2011) Quantitative characteristics of timberline vegetation on Mt. Shergyla, Tibet. Journal of Beijing Forestry University 33(3):45-50. DOI: 10.13332/j.1000-1522.2011.03.001 (In Chinese)

Zhang L, Luo TX, Liu XS, et al. (2010) Altitudinal variations in seedling and sapling density and age structure of timberline tree species in the Sergyemla Mountains, southeast Tibet. Acta Ecologica Sinica 30(2): 76-80. DOI: 10.1016/j.chnaes. 2010.03.005

Zhang XJ, Luo DQ (2013) Community structure and species diversity of Abies georgei var. smithii forest near the timerline. Journal of Northwest Forestry University 28(2): 1-7. DOI: 10.3969/j.issn.1001-7461.2013.02.01 (In Chinese) 